\title{
On the enchytraeid fauna of Köszeg Mountains with description of a new Fridericia species (Clitellata, Enchytraeidae).
}

\author{
K. DÓZSA-FARKAS ${ }^{1} \&$ T. FELFÖLDI ${ }^{2}$ \\ ${ }^{I}$ Klára Dózsa-Farkas, Department of Systematic Zoology and Ecology, ELTE Eötvös Loránd University, \\ H-1117 Budapest, Pázmány Péter sétány 1/C, Hungary.E-mail: kdozsafarkas@gmail.com \\ ${ }^{2}$ Tamás Felföldi, Department of Microbiology, ELTE Eötvös Loránd University, H-1117 Budapest, \\ Pázmány Péter sétány 1/C, Hungary. E-mail: tamas.felfoldi@gmail.com
}

\begin{abstract}
The enchytraeid fauna of Köszeg Mountains (Western Hungary and Eastern Austria), hitherto unknown, was investigated in this study. Fifteen enchytraeid genera including 59 species and two other annelid worms (Hrabeiella periglandulata Pižl \& Chalupský, 1984 and Parergodrilus heideri Reisinger, 1925) were identified. The latter is a new record for Hungary. One enchytraeid species, proved to be new to science, is described in this paper as Fridericia szoevenyii sp. nov. The new species is distinguished from similar species on the basis of both morphological characters and molecular data (mitochondrial cytochrome c oxidase subunit I and nuclear histone 3 gene sequences). Based on the presence of subalpinealpine species, the enchytraeid fauna of Köszeg Mountains is similar to that of Rax Mountains (Northern Alps, Austria). The two most species-rich sites were the alder carr at a creekside near Paprét (33 species) and a mesophile montane hay meadow at Steirer Houses (27 species). Interestingly, a mixed forest with dense underwood of Vaccinium myrtillus harbored only a single species.
\end{abstract}

Key words. new Friedericia species, enchytraeid fauna, Kőszeg Mts., CO1 gene

\section{INTRODUCTION}

$\mathrm{T}$ he enchytraeid fauna of western Hungary (Köszeg Mountains and Örség National Park) was studied between 2014-2016. The composition of enchytraeid fauna in Örség National Park has already been published (Dózsa-Farkas \& Felföldi 2016). Two other works (Dózsa-Farkas et al. 2017 and Dózsa-Farkas \& Felföldi 2017a) dealt with the comparative morphological and molecular taxonomic analysis of Cernosvitoviella and Achaeta species of this area including the description of a new Cernosvitoviella and a new Achaeta species (C. farkasi and A. tothi, respectively). Here, we present the faunistic results from Köszeg Mountains with the description of a new Fridericia species, Fridericia szoevenyii sp. nov. The morphological studies was supplemented with molecular taxonomic analysis targeting the mitochondrial cytochrome c oxidase subunit I (CO1) and nuclear histone 3 (H3) genes.

\section{MATERIAL AND METHODS}

Study area. Köszeg Mountains is the easternmost unit of the Alps, and has an area of $c a .60$ $\mathrm{km}^{2}$. The territory of the mountain range is shared between Austria and Hungary. The highest point of Köszeg Mts. is Írott-kő with a height of $883 \mathrm{~m}$, but the majority of this area is hilly with an average altitude of 300-700 m. The main mass of the mountains is built of crystalline rocks (schist). The mean annual temperature of this region is $9.2^{\circ} \mathrm{C}$, at the Steirer Houses site is $8.5-9.0^{\circ} \mathrm{C}$. The mean temperature in January is $-2-3^{\circ} \mathrm{C}$, the mean temperature in July is $19^{\circ} \mathrm{C}$. The winter is mild and due to the low temperature fluctuation, submediterranean vegetation could also be found, but the cool summer favors dealpine elements in the flora. Annual sunshine hours has the lowest value in this region within Hungary $(<1800 \mathrm{~h})$. The average precipitation in the last 50 years was $779 \mathrm{~mm}$ in Köszeg town (285 m a.s.1.) and 912 
$\mathrm{mm}$ at Steirer Houses (551 $\mathrm{m}$ a.s.1.) with a maximum in July. Majority of this area belongs to the mountain beech forest zone. The characteristic soil types are non-podzolic brown forest soils, which are extremely acidic, while in the deeper valleys pseudogley brown forest soils are more common (Markovics 1994).

Collection sites. In total, 20 macro- and microhabitats were sampled at 16 localities (Appendix 1).

Morphological methods. Animals were extracted from the soil by the wet funnel method (O'Connor 1962). Worms were first studied and measured alive, and subsequently preserved in $70 \%$ ethanol. Later, a part of the adult specimens was stained with borax-carmine then passed through an ethanol (70\% to absolute) dehydration series, mounted temporarily in clove oil, and later mounted in Euparal on a slide between two coverslips. The important morphological structures were recorded in vivo, drawn, and photographed using an Axio Imager.A2 microscope with DIC (differential interference contrast) illumination and an AxioCam MRc 5 (Zeiss) digital camera with Axiovision software. The whole-mounted specimens were reinvestigated and also photographed. Holotype and paratypes of the new species are deposited in the collection of the Department of Systematic Zoology and Ecology, Eötvös Loránd University (Budapest, Hungary).

Methods of molecular analysis. Genomic DNA was extracted from the specimens with the DNeasy Blood \& Tissue Kit (Qiagen) following the instructions given by the manufacturer. The mitochondrial cytochrome $\mathrm{c}$ oxidase subunit I (CO1) and the nuclear histone $3(\mathrm{H} 3)$ genes were amplified using the primers HCO2198 (5'-TAA ACT TCA GGG TGA CCA AAA AAT CA-3') and LCO1490 (5'-GGT CAA CAA ATC ATA AAG ATA TTG G-3') (Folmer et al. 1994), and H3a-F (5'-ATG GCT CGT ACC AAG CAG ACV GC-3') and H3a-R (5'-ATA TCC TTR GGC ATR ATR GTG AC-3') (Colgan et al. 1998) [if amplification failed, with primers designed by
AllGenetics, A Coruña (and used here with permission of ECT Oekotoxikologie $\mathrm{GmbH}$, Flörsheim), H3Frid-M13F (5'-GTA AAA CGA CGG CCA GTT ACC AAG CAG ACG GCH CGY-3') with H3Frid-M13tR (5'-GCG GAT AAC AAT TTC ACA CAG GGG CGT GAA TBG CRC ACA GGT-3')], respectively. PCRs were performed applying the parameters given by Dózsa-Farkas \& Felföldi (2015). Purification and sequencing of PCR products were carried out by LGC Genomics GmbH (Berlin, Germany). Removal of primer sequences and manual correction of automatic base calling on chromatograms were performed using the Chromas software v. 1.45 (Technelysium). Phylogenetic analysis (which included the search for the best-fit model) was conducted with the MEGA 7.0 software (Kumar et al. 2013). Sequences determined in this study were deposited in GenBank under the following accession numbers: MF142359-MF142361 (CO1) and MF361128MF361130 (H3).

\section{RESULTS}

\section{Results of morphological analysis}

In total, 59 species were recorded which belonged to 15 enchytraeid genera, moreover two terrestrial polychaete species, Hrabeiella periglandulata Pižl \& Chalupský, 1984 and Parergodrilus heideri Reisinger, 1925 were also detected in the samples (Appendix 1). Parergodrilus heideri is a new record for the fauna of Hungary, while all enchytraeid species represent new records for the Köszeg mountain range. One species (described here as $F$. szoevenyii sp. nov.) is new to science and the status of Fridericia sp. and Enchytraeus sp. has not been ascertained yet. Probably, they also represent new species for science, but further investigations are needed to clarify their taxonomic status. A list of species recorded in individual samples, which represented microhabitats at the studied sites, is given in Appendix 1.

It should be mentioned that the presence of the terrestrial polychaete Parergodrilus heideri, was 
recorded not during this sampling campaign, but was found earlier and but has not been published yet.

These samples were collected at a site near Velem village, in a mixed deciduous forest (hornbeam-oak-beech-pine), $47^{\circ} 35.194 \mathrm{~N}, 16^{\circ} 48.583 \mathrm{E}$, $430 \mathrm{~m}$ a.s.1., 07.09.2008, leg. B. Németh. About the anatomy of this very small polychaeta $(0.8-1$ mm long, Fig. 4A-B) detailed description can be found in Reisinger (1925, 1960), Karling (1958), Rota (1998), and ultrastructure analysis in Purschke (1987, 1988, 2002). Here, only some micrographs on the Hungarian female specimens are given (only female specimens were found): forepart (Fig. 4C-D) and body-end (Fig. 4E-F), the nephridia in II-III segments (Fig. 4G) and the chaetae at the body-end (Fig. 4H).

\section{DESCRIPTION OF THE NEW SPECIES}

\section{Fridericia szoevenyii sp. nov.}

(Figures 1-3)

Type material. Holotype. F. 28. slide No. 2138, DNS 939, Velem, in Irottkő landscape protection area, Hungary, streamside area of willow (site 16.a), $47^{\circ} 20.271 \mathrm{~N}, 16^{\circ} 30.047 \mathrm{E}, 325 \mathrm{~m}$ a.s.l., 27.03.2016. Leg. G. Szövényi. Paratypes. In total 6 specimens. P.111.1-111.6 slide No. 2139, 2142-2143, 2145-2147, at the type locality, 27.03.2016.

Etymology. Named in the honor of our colleague, Dr. Gergely Szövényi, who collected samples with this species.

Diagnosis. The new species can be recognized by the following combination of characters: (1) large size (body length 13-19 $\mathrm{mm}$ in vivo), segments 44-56; (2) maximum 4 chaetae per bundle; (3) clitellum weakly and only laterally developed, interrupted ventrally and dorsally, hyalocytes and granulocytes arranged in transverse rows; (4) five preclitellar pairs of nephridia;
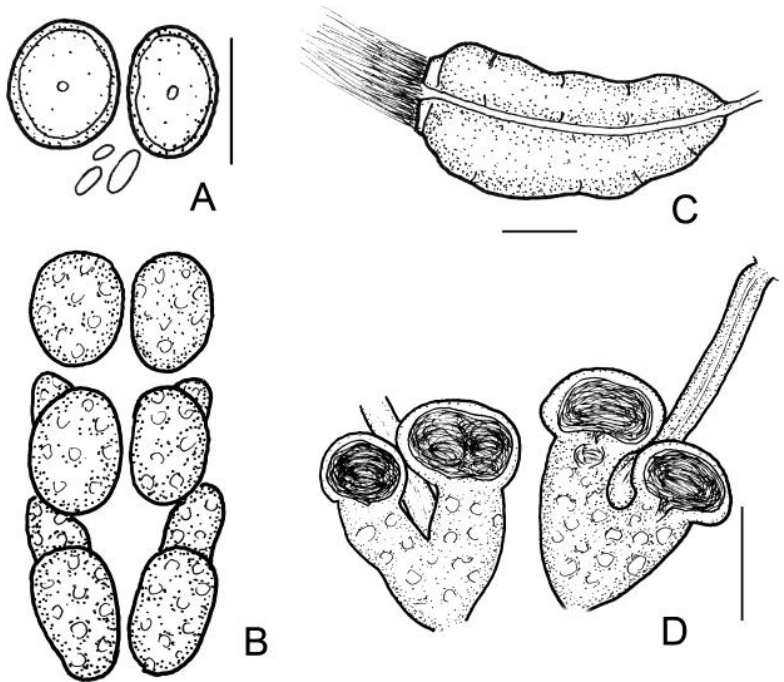

Figure 1. Fridericia szoevenyii sp. nov. $\mathrm{A}=$ coelomocytes, $\mathrm{B}=$ pharyngeal glands in dorsal view, $\mathrm{C}=$ sperm funnel, $\mathrm{D}=$ spermathecae; schematic, scale bars $=100 \mu \mathrm{m}$ (exept in A $50 \mu \mathrm{m}$ )

(5) coelomo-mucocytes b-type with a thickened cell border, lenticytes large 10-23 $\mu \mathrm{m}$; (6) chylus cells in IX-X; (7) bursal slit H-shaped; (8) seminal vesicle in XI; (9) subneural glands absent; (10) sperm funnel cylindrical, approximately as long as body diameter or slightly shorter, collar narrower as funnel body, sperm 120-170 $\mu \mathrm{m}$ long, sperm heads 50-80 $\mu \mathrm{m}$ long (in vivo); (11) spermathecae separate entally, with two large stalked, spherical diverticula, ectal glads absent.

Description. Large, milk-white (caused by the large chloragocytes filled with very strong refractile vesicles), strong and slow-moving worms. Holotype $15.3 \mathrm{~mm}$ long, $380 \mu \mathrm{m}$ wide at VIII and $490 \mu \mathrm{m}$ at the clitellum (in vivo). The fixed worms $9.3 \mathrm{~mm}$ long $480 \mu \mathrm{m}$ wide at VIII and 500 $\mu \mathrm{m}$ at the clitellum, 44 segments (from the last 8 segments, a $2.15 \mathrm{~mm}$-long region was removed for molecular analysis). Body length of the paratypes $13-17.5 \mathrm{~mm}$, width $350-450 \mu \mathrm{m}$ at VIII and $400-540 \mu \mathrm{m}$ at the clitellum (in vivo). Length of fixed specimens $8.3-11 \mathrm{~mm}$, width $400-480 \mu \mathrm{m}$ at VIII and $420-450 \mu \mathrm{m}$ at the clitellum. 

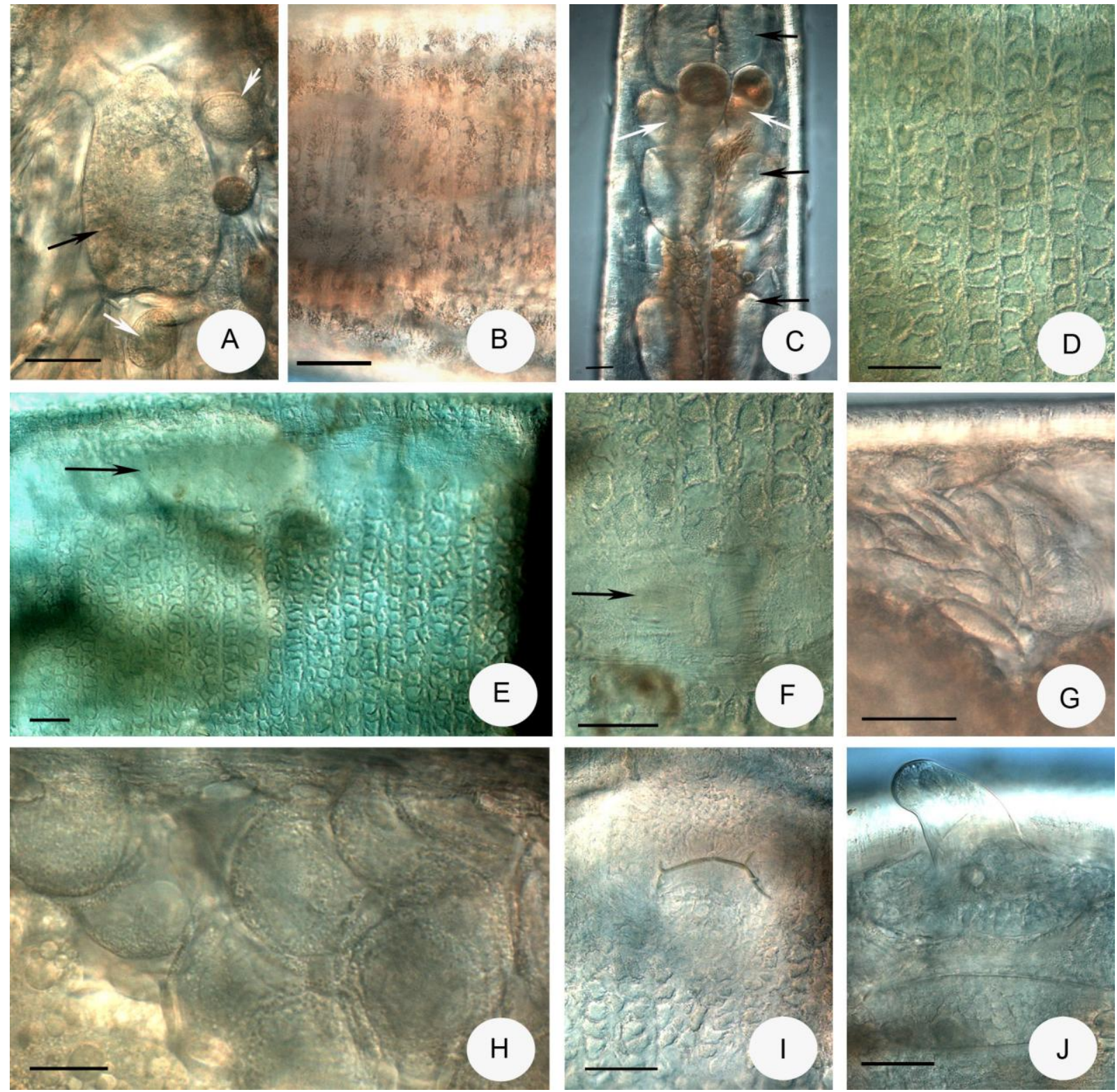

Figure 2. Micrograph of Fridericia szoevenyii sp. nov. A = brain (coelomo-mucocytes marked with arrows), $\mathrm{B}=$ epidermal glands, $\mathrm{C}=$ pharyngeal glands (marked with black arrows, spermathecae marked with white arrows), $\mathrm{D}=$ clitellar glands in lateral view, $\mathrm{E}=$ clitellar glands in dorso-lateral view (dorsal gap marked with arrow), $\mathrm{F}=$ dorsal gap of clitellar glands (marked with arrow), $\mathrm{G}-\mathrm{H}=$ coelomocytes, $\mathrm{I}=$ bursal slit, $\mathrm{J}=$ everted bursa; all in vivo; scale bars $=50 \mu \mathrm{m}$ (except in $\mathrm{H}=20 \mu \mathrm{m})$.

Segments 44-56. Chaetal formula: 2,3,4,5 $4,3,2:(2), 3,4-4,3,(0), 2$. In segment XII two chaetae present laterally. As in other Fridericia species, chaetae in bundles arranged in pairs with the outer pairs being longer and thicker than the inner pairs: $70-73 \times 4-5 \mu \mathrm{m}$ against $41-48 \times 3.5-$
$4 \mu \mathrm{m}$ (preclitellar bundles), after the clitellum about in 10-15 segments slightly shorter. At the body-end only 2 chaetae per bundle, size about $60-80 \times 5 \mu \mathrm{m}$. Head pore at 0/I. Dorsal pores from VII. Epidermal gland cells mostly weakly developed sometimes 5-6 brownish glands (in 
transmittent light) in transverse rows (Fig. 2B). Clitellum in XII-1/2XIII, only laterally, hyalocytes and granulocytes arranged in transverse rows, about the same size $(14-19 \mu \mathrm{m}$, in vivo) (Fig. 2D), dorsally and ventrally absent,
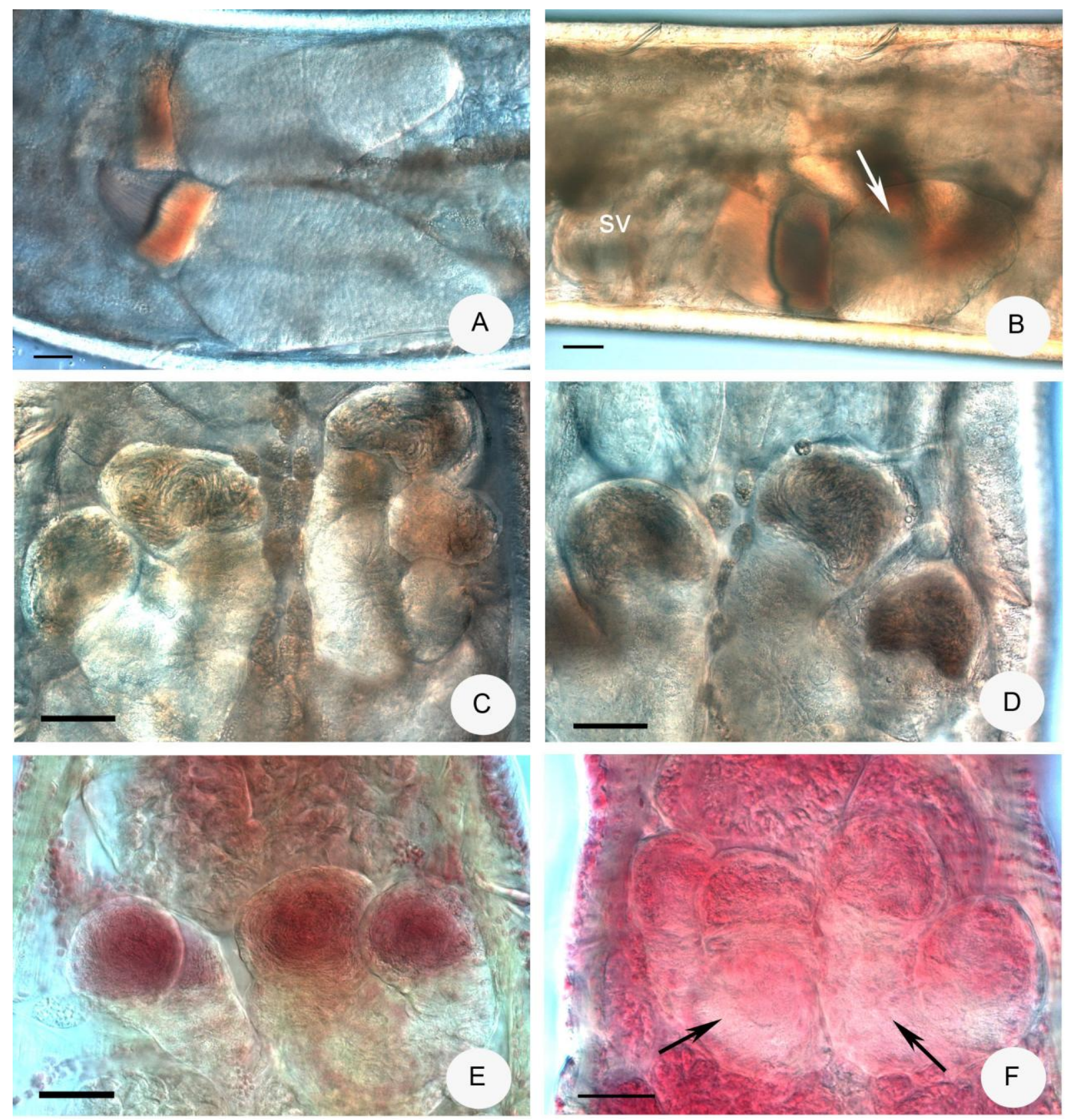

Figure 3. Micrograph of Fridericia szoevenyii sp. nov. A-B = sperm funnels (in B marked with arrow, $\mathrm{sv}=$ seminal vesicle) $\mathrm{C}-\mathrm{F}=$ spermathecae (in F marked with arrows); $\mathrm{A}-\mathrm{D}$ in vivo, $\mathrm{E}-\mathrm{F}$ fixed, stained; scale bars $=50 \mu \mathrm{m}$. 
longer than wide in vivo (Fig. 2A), and $120 \mu \mathrm{m}$ in the fixed specimens. Oesophageal appendages atype, short, with wide lumen, without branches. All pharyngeal glands free dorsally, with ventral lobes in $\mathrm{V}$ and VI, all primary lobes ca. the same in size (Fig. 1B, 2C). Chloragocytes from V, 28$33 \mu \mathrm{m}$ long and dark-brown in transmittent light in vivo, therefore the worms have milk-white color under top light. Dorsal vessel from XV-XVI, blood colourless. Midgut pars tumida not observable. Five pairs of preclitellar nephridia from $6 / 7$ to $10 / 11$, length ratio anteseptale : postseptale about $1: 1$ or preseptale slightly shorter than postseptale, midventral origin of efferent duct. Coelomo-mucocytes with refractile vesicles mainly peripherally with a thickened cell border (length 36-50 $\mu \mathrm{m}$ in vivo, (22-23 $\mu \mathrm{m}$ fixed), lenticytes large and wide $11-20$ by $6-7 \mu \mathrm{m}$ in vivo (Fig. 1A, 2G-H), fixed 8-10 $\mu \mathrm{m}$. Chylus cells between IX-X, occupying 2 segments, difficult to observe. Seminal vesicle in XI not brown (Fig. 3B). Sperm funnel (Figs. 1C, 3A-B) cylindrical, approximately as long as body diameter or slightly shorter, about $300-500 \mu \mathrm{m}$ long in vivo and $150-200 \mu \mathrm{m}$, fixed, 1.5-2 times as long as wide, collar narrower as funnel body, spermatozoa about $120-170 \mu \mathrm{m}$ long, sperm heads $50-80$ $\mu \mathrm{m}$ long in vivo, while in fixed specimens $85-100$ $\mu \mathrm{m}$ and 30-35 $\mu \mathrm{m}$, respectively. Diameter of sperm ducts $9 \mu \mathrm{m}$ (in vivo). Male copulatory organs 180-200 $\mu \mathrm{m}$ long, 100-130 $\mu \mathrm{m}$ wide and $70-80 \mu \mathrm{m}$ high (in vivo) (170-185, 90-100 and $40-60 \mu \mathrm{m}$ in fixed specimens, respectively) with large evertable bursa (Fig. 2J). Bursal slits longitudinal with additional transverse extension or H-shaped (Fig. 2I). Subneural glands absent. Spermathecae (Figs. 1D, 3C-F): no ectal gland, ectal ducts about 200-270 $\mu \mathrm{m}$ long and 25-27 $\mu \mathrm{m}$ wide, canal $5 \mu \mathrm{m}$ in vivo (180-230 $\mu \mathrm{m}$ long, 21$26 \mu \mathrm{m}$ wide, fixed). Duct projecting into ampulla without ental bulb. Ampullae longer than wide, about 100-125 $\mu \mathrm{m}$ wide (fixed), thick-walled, tapering proximad, no separation into distal and proximal part. Separate communication of ampullae with oesophagus. Two very large spherical diverticula with unequally long, thick-walled stalks (length of stalks 50-65 $\mu \mathrm{m}$ in vivo, 35-55 $\mu \mathrm{m}$ fixed). The diverticula thin-walled, diameter 75-100 $\mu \mathrm{m}$ in vivo and fixed alike, mostly filled with brown sperm (in transmitted light), sperm not rotating. One, rarely two mature eggs at a time.

Distribution and habitat. Known only from the type locality: Velem, in Irottkö landscape protection area in the western geographic region of Hungary, creekside area of willow, $47^{\circ} 20.271 \mathrm{~N}$ $16^{\circ} 30.047$ E, 325 m. a.s.l.

Remarks. The new species can easily be distinguished from all Fridericia species that also possess two globular spermathecal diverticula with well-developed stalks, and entally separate ampullae: F. rendsinata Dózsa-Farkas, 1972, F. perrieri (Vejdovksý, 1878), F. healyae Schmelz, 2003, F. dozsae Schmelz, 2003, F. omeri Stephenson, 1932 and $F$. galba (here the form with 2 spermathecal diverticula, see Dózsa-Farkas 2009, Table 5), moreover from $F$. connatiformis Dózsa-Farkas, 2015. The new species differs from all these species leaving other characters out of consideration, by the very large spermathecal diverticula without ciliated subchambers, so that sperm is not rotating, by the origin of dorsal vessel in XV-XVI (in the other species more backwards) and by the preclitellar position of the chylus cells. Additionally, F. perrieri, F. healyae, $F$. dozsae, $F$. omeri and $F$. galba have more than 4 chaetae in a bundle, and $F$. connatiformis has only 2 chaetae in a bundle and larger extra sexual glands.

\section{Results of molecular analysis}

Two specimens (including the holotype) of Fridericia szoevenyii sp. nov. were subjected to molecular taxonomic analysis. Based on the mitochondrial $\mathrm{CO} 1$ and nuclear $\mathrm{H} 3$ genes, sequences of the new species formed highly supported (100\% and $99 \%$ bootstrap value respectively) and well separated clades on the phylogenetic trees (Fig. 5) which confirms that $F$. szoevenyii sp. nov. is a distinct species. 

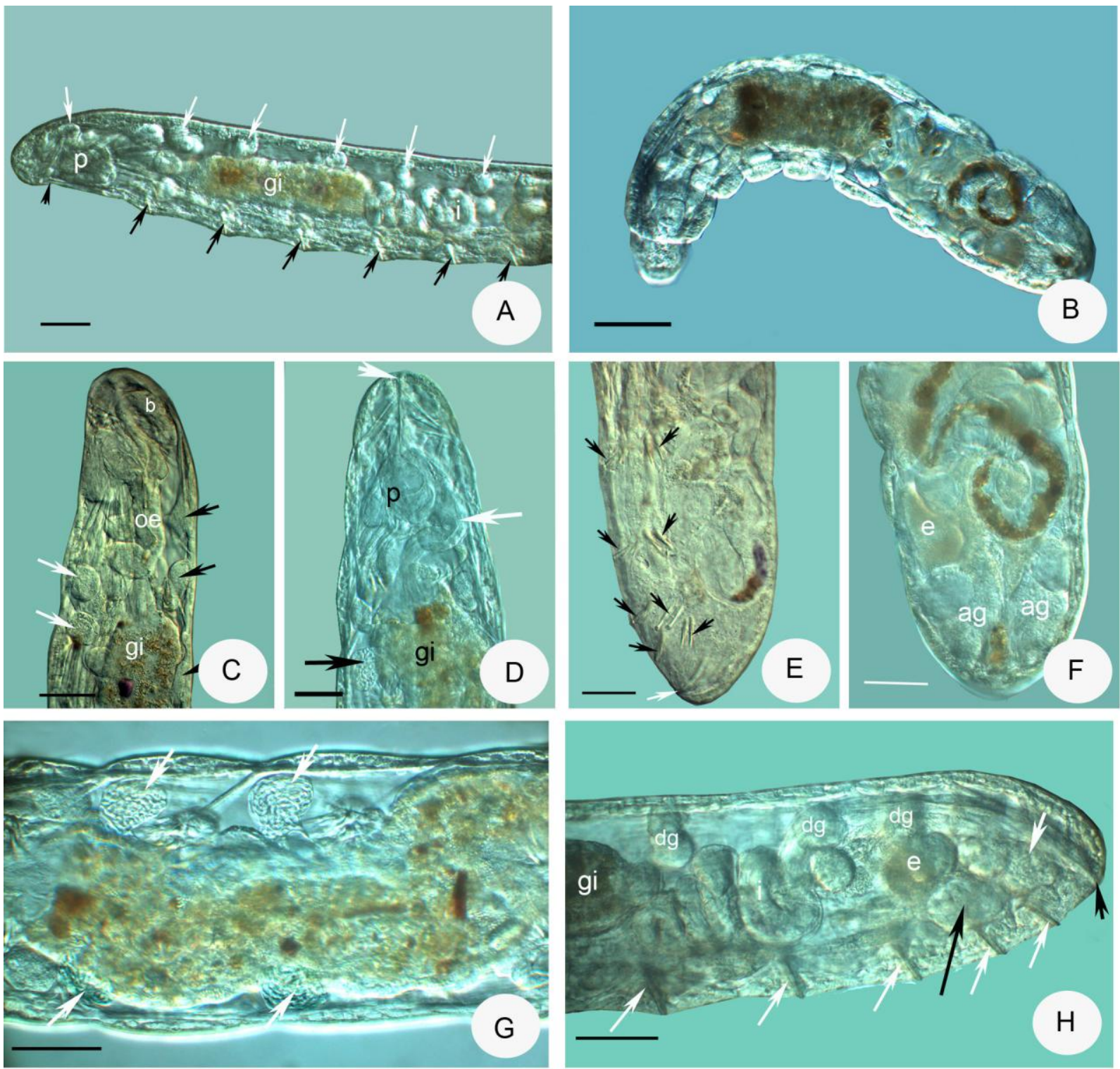

Figure 4. Micrograph of Parergodrilus heideri Reisinger, 1925. A-B = entire specimens (chaetae marked with black arrows, dorsal glands marked with white arrows, mouth marked with short arrow, $\mathrm{p}=$ pharynx, gi $=$ gastrointestine, $\mathrm{I}=$ intestine), $\mathrm{C}=$ forepart of body lateral view (dorsal glands marked with black arrows, ventral glands marked with white arrows, $b=$ brain, oe $=$ oesophagus, gi = gastrointestine, $\mathrm{D}=$ forepart of body dorsal view (oesophages marked with white arrow, nephridium marked with black arrow, mouth marked with short white arrow, $\mathrm{p}=$ pharynx, gi = gastrointestine), $\mathrm{E}=$ body-end lateral view (chaetae marked with black arrows, anus marked with white arrow), $\mathrm{F}=$ body-end dorsal view ( $\mathrm{ag}=$ anal glands, $\mathrm{e}=\mathrm{egg}$ ), $\mathrm{G}=$ nephridia in II-III segments (marked with arrows), $\mathrm{H}=$ posterior part of body lateral view (chaetae marked with white arrows, anal gland marked with short white arrow, subneural gland marked with long black arrow, anus marked with short black arrow, gi $=$ gastrointestine, $\mathrm{dg}=$ dorsal glands, $\mathrm{e}=\mathrm{egg}$ ). 

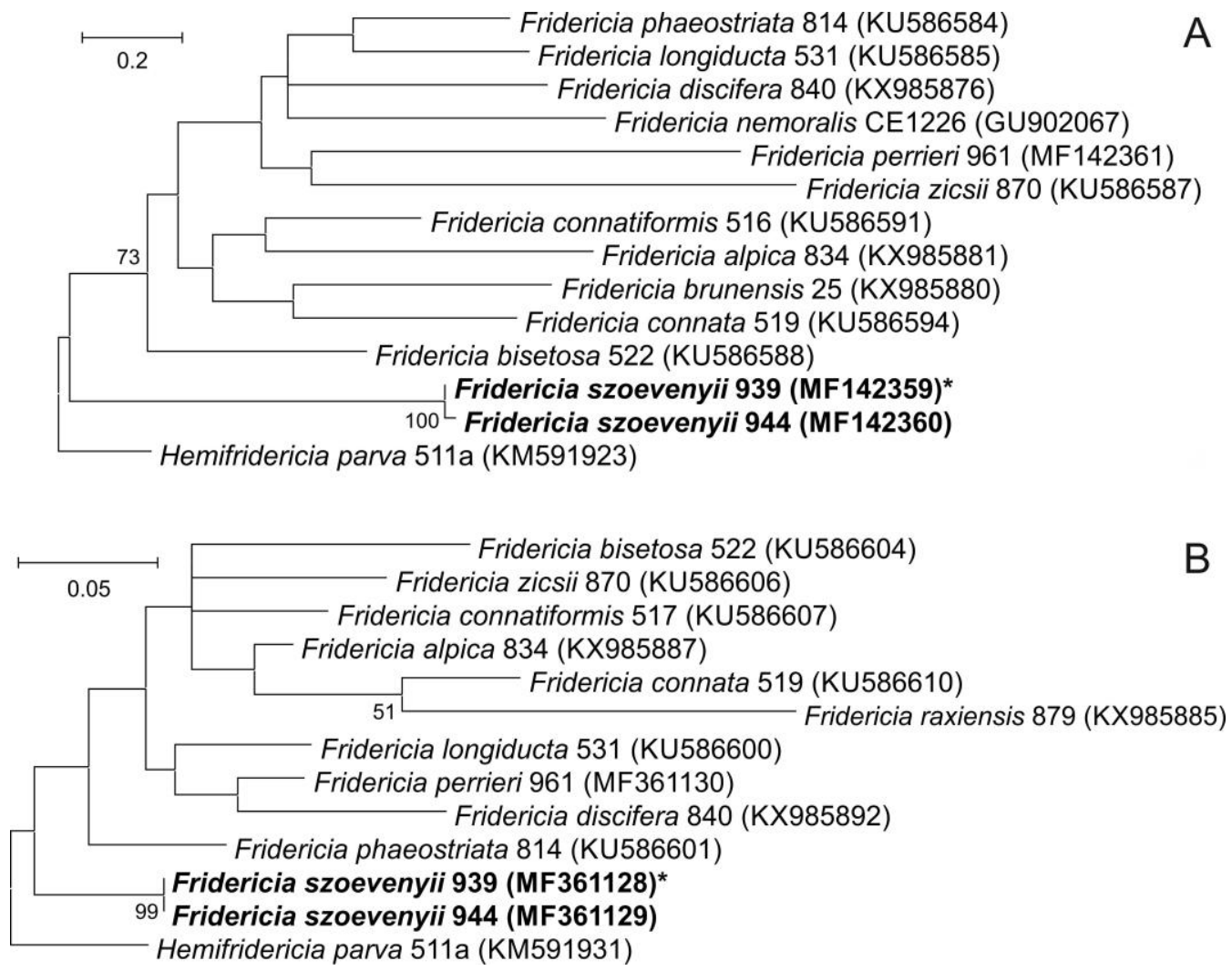

Figure 5. Maximum likelihood phylogenetic tree of selected Fridericia species based on the CO1 (A) and H3 (B) genes (439 and 181 nucleotide positions, TN93+G+I and $\mathrm{K} 2+\mathrm{G}$ substitution models, respectively). Bootstrap values greater than 50 are shown at the nodes. Sequences from the new species described here appear in bold (holotype marked with an asterisk).

\section{DISCUSSION}

The diverse enchytraeid fauna consisting of 59 species distributed in 15 genera (Appendix 2) of Köszeg Mts. is worth comparing with the fauna of Rax Mts. in Austria (Dózsa-Farkas \& Felföldi 2017b); both have subalpine or alpine climate. Comparing these two regions, similarities could be found regarding the enchytraeid fauna, which includes some characteristic species of the Alps. For example, $F$. alpica described from Rax was also found in Köszeg Mts., moreover, at site 15a (alder carr at creekside) with its very cool and humid subclimate, a habitat is provided for such species as $F$. discifera, $F$. raxiensis, Euenchytraeus clarae and Fridericia sp. This latter represents a new species within the genus which will be described soon. Additionally, these four species were recorded only from the Köszeg Mts (in site 15a) and nowhere else within Hungary, therefore they could be regarded as relict species from the Ice age.

Euenchytraeus clarae is possibly identical with Euenchytraeus bisetosus, which was described by Bretscher (1906) from Swiss Alps but, based on immature material (Schmelz \& Collado 2010, Martinsson et al. 2014). For the correct synonimization, it will be necessary to compare individuals from the type locality with those from Köszeg Mts. It is also worth mentioning that Oconnorella tubifera, which is widespread from Sweden to Italy in moist soils (Schmelz \& Collado 2010), was found at first time in Hungary in the Köszeg Mts., only from the sites 15a (alder carr along a creek) and site 10 (spruce forest).

From Köszeg Mts., three new species, namely Fridericia szoevenyii sp. nov. (described here), Achaeta tothi Dózsa-Farkas \& Felföldi, 2017 and 
Cernosvitoviella farkasi, Dózsa-Farkas et al., 2017 were also found. Two of them occurred only in one locality: $F$. szoevenyii only at site 16 a (Velem, area of willow along a creek) and $C$. farkasi only at site 8b (Ólmod, young Scots pine forest in stagnant mud); while $A$. tothi were recorded from three sites: site 10 (near Hörmannspring, spruce forest), site 12 (Steirer Houses, mesophile montane hay meadow) and site 11 (between Hörmann-spring and Velem village, mixed forest). It is possible that all are endemic to this region.

In terms of species numbers recorded at the investigated sites, the alder carr at a creekside near Paprét (site 15) showed the highest value with 33 species. The second is in this regard was the mesophile montane hay meadow at Steirer Houses (site 13) with 27 species. Remarkable that in a mixed forest on a hillside (site 12) only a single species (Marionina clavata) was found, probably due to the dense underwood of Vaccinium myrtillus.

Acknowledgements - Many thanks to Dr. Zoltán Tóth, Dr. János Farkas and Dr. Gergely Szövényi for their assistance in sampling. The authors are thankful to Hajnalka Nagy and Bianka Csitári for their technical assistance during DNA studies. This research was financed by the National Research, Development and Innovation Office (108582 NKFIH).

\section{REFERENCES}

Colgan, D.J., Mclauchlan, A.A., Wilson, G.D.F., LivingSTON, S.P., EDGECOMBE, G.D., MACARANAS, J., CASSIS, G. \& GRAY, M.R. (1998): Histone H3 and U2 snRNA DNA sequences and arthropod molecular evolution. Australian Journal of Zoology, 46: 419-437. doi: 10.1071/ZO98048

DÓZSA-FARKAS, K. \& FELFÖLDI, T. (2015): Unexpected occurrence of Hemifridericia bivesiculata Christensen \& Dózsa-Farkas, 2006 in Hungary, a species presumed to be endemic to Devon Island, Canada, and its comparative analysis with $H$. parva Nielsen \& Christensen, 1959 (Enchytraeidae, Oligochaeta). Zootaxa, 3914 (2): 185-194. doi: $10.11646 /$ zootaxa.3914.2.8

DÓzSA-FARKAS, K. \& FELFÖLDI, T. (2016): A new Fridericia species (Clitellata, Enchytraeidae) and the enchytraeid fauna of the Örség National park (Hungary). Opuscula Zoologica Budapest, 47 (1): 65-72. doi: 10.18348/opzool.2016.1.65

DÓZSA-FARKAS, K. \& FELFÖLDI, T. (2017a): Comparative morphological and molecular taxonomic study of six Achaeta species (Clitellata: Enchytraeidae) with the description of a new Achaeta species from Köszeg Mountains, Hungary. Zootaxa, 4273 (2): 177-194. doi: 10.11646/zootaxa.4273.2.2

DÓZSA-FARKAS, K. \& FELFÖLDI, T. (2017b): The enchytraeid fauna (Enchytraeidae, Clitellata) of Rax Mountain (Austria) with the description of two new species and comparison of Fridericia discifera Healy, 1975 and F. alpica sp. n. Acta Zoologica Academiae Scientiarum Hungaricae, (in print).

DÓzSA-FARKAS, K., CSITÁRI, B. \& FElföldi, T. (2017): A new Cernosvitoviella species (Clitellata: Enchytraeidae) and its comparison with other Cernosvitoviella species from Sphagnum mires in Hungary. Zootaxa, 4254 (3): 322-338 doi: $10.11646 /$ zootaxa.4254.3.2

Folmer, O., Black, M., HoEH, W., Lutz, R. \& VRIJENHOEK, R. (1994): DNA primers for amplification of mitochondrial cytochrome c oxidase subunit I from diverse metazoan invertebrates. Molecular Marine Biology and Biotechnology, 3: 294-299.

KARLING, T.G. (1958): Zur Kenntniss von Stygocapitella subterranea Knöllner und Parergodrilus heideri Reisinger (Annelida). Arkiv för Zoologie (s.2), 11: 307-342.

Kumar, S., Stecher, G. \& TAMURA, K. (2016): MEGA7: Molecular Evolutionary Genetics Analysis version 7.0 for bigger datasets. Molecular Biology and Evolution, 33(7): 1870-1874. doi: $10.1093 / \mathrm{molbev} / \mathrm{msw} 054$

MARKovics, T. (1994): A Köszegi-hegység természetföldrajzi képe. In. BARTHA, D. (Ed.) A Kőszegihegység vegetációja, Erdészeti és Faipari egyetem Jegyzetsokszorosítója, p. 8-12.

Martinsson, S., Rota, E. \& Erséus, C. (2015): Revision of Cognettia (Clitellata, Enchytraeidae): re-establishment of Chamaedrilus and description of cryptic species in the sphagnetorum complex. Systematics and Biodiversity, 13(3): 257-277. doi: $\underline{10.1080 / 14772000.2014 .986555}$

O'CONNOR, F.B. (1962): The extraction of Enchytraeidae from soil. In. MURPHY, P.W. (Ed.) 
Progress in Soil Zoology, Butterworths Publishers, London, p. 279-285.

PURSCHKE, G. (1987): Anatomy and ultrastructure of ventral pharyngeal organs and their phylogenetic importance in Polychaeta (Annelida). III. The pharynx of the Parergodrilidae. Zoologische Jahrbücher, Abteilung für Anatomie und Ontogenie der Tiere 115: 331-362.

PurschKe, G. (1988): Pharynx. In. Westheide, W., HERMANS, C.O. (Eds.) The untrastructure of Polychaeta. Microfauna Marina 4: 177-197.

PURSCHKE, G. (2002): Male genital organs spermatogenesis and spermatozoa in the enigmatic terrestrial polychaete Parergodrilus heideri (Annelida, Parergodrilidae). Zoomorphology, 121: 125-138. doi: $\underline{10.1007 / \mathrm{s} 004350100050}$
REISINGER, E. (1925): Ein landbewohnender Archiannelide. (Zugleich ein Beitrag zur Systematik der Archianneliden). Zeitschrift für Morphologie und Ökologie der Tiere, 3: 197-254.

REISINGER, E. (1960): Die Lösung des ParergodrilusProblems. Zeitschrift für Morphologie und Ökologie der Tiere, 48: 517-544.

RotA, E. (1998): Morphology and adaptations of Parergodrilus Reisinger and Hrabeiella Pizl and Chalupsky, two enigmatic soil-dwelling annelids. Italian Journal of Zoology, 65: 75-84. doi: 10.1080/11250009809386727

Schmelz, R.M. \& Collado, R. (2010): A guide to European terrestrial and freshwater species of Enchytraeidae (Oligochaeta). Soil Organisms, 82 (1): $1-176$. 
Appendix 1. Investigated sites and habitats (with sampling dates) in Köszeg Mts. with the recorded enchytraeid and the two Polychaeta species (dominant species are underlined).

1. Near Reichnitz, Austria, mixed deciduous forest with Fagus silvatica and Quercus petreae, $47^{\circ} 20.194^{\prime} \mathrm{N}, 16^{\circ} 23.993^{\prime} \mathrm{E}, 671 \mathrm{~m}$ a.s.l., 21.05.2014. 8+1 species (Chamaedrilus chlorophilus, Enchytraeus norvegicus, Enchytronia parva, Fridericia bisetosa, F. alpica, F. sohlenii, Mesenchytraeus glandulosus, Oconnorella cambrensis, Hrabeiella periglandulata).

2. Near Reichnitz, Austria, mixed forest with Fagus silvatica, Quercus petreae, Pinus silvestris, $P$. nigra and Picea abies, $47^{\circ} 19.749^{\prime}$ $\mathrm{N}, 16^{\circ} 25.666^{\prime} \mathrm{E}, 634 \mathrm{~m}$ a.s.1., 21.05.2014. 6 species (Achaeta cf. danica, Bryodrilus ehlersi, Buchcholzia appendiculata, Enchytraeus buchcholzi s.l., E. norvegicus, Marionina clavata).

3. Near Reichnitz, Austria, clearing in the woodland, $47^{\circ} 20.195^{\prime} \mathrm{N}, 16^{\circ} 23.992^{\prime} \mathrm{E}, 624 \mathrm{~m}$ a.s.1., 21.05.2014. 8 species (Buchcholzia appendiculata, Enchytraeus buchcholzi s.l., Enchytronia parva, Fridericia benti, F. bisetosa, F. bulboides, F. miraflores, Henlea perpusilla).

4. Between Reichnitz and Lockenhaus, Austria, spruce (Picea abies) forest, $47^{\circ} 20.195^{\prime} \mathrm{N}$, 16 ${ }^{\circ} 23.992^{\prime} \mathrm{E}, 739 \mathrm{~m}$ a.s.1., 21.05. 2014. 3 species (Achaeta cf. danica, Enchytraeus norvegicus, Fridericia dura).

5. Hammerteich, Austria, hay meadow, $47^{\circ} 24.630^{\prime} \mathrm{N}, 16^{\circ} 26.680^{\prime} \mathrm{E}, 327 \mathrm{~m}$ a.s.l., 21. 05.2014. 8 species (Enchytraeus bulbosus, Enchytronia christenseni, En. parva, Fridericia bisetosa, $F$. bulboides, $F$. connata, $F$. miraflores, $F$. paroniana)

6. Alsóerdö, Hungary, old Sphagnum mire, $47^{\circ} 40.370^{\prime} \mathrm{N}, 16^{\circ} 56.460^{\prime} \mathrm{E}, 350 \mathrm{~m}$ a.s.l., 31. 10.2014. 4 species (Cernosvitoviella atrata, $C$. minor, Chamaedrilus chlorophilus, Mesenchytraeus pelicensis).

7. Alsóerdő, Hungary, mixed forest near an old Sphagnum mire, $47^{\circ} 24.241^{\prime} \mathrm{N}, 16^{\circ}$
33.882' E, $345 \mathrm{~m}$ a.s.1., 27.03.2016. 5 species (Achaeta affinis, A. camerani, Chamaedrilus chlorophilus, Marionina clavata, Mesenchyraeus pelicensis)

8. Near Ólmod, Hungary, $47^{\circ} 24.345^{\prime} \mathrm{N}$, $16^{0} 33.918^{\prime}$ E, 319 m a.s.l.

a. Sphagnum mire, 21.05.2014, 13.10.2014. 4 species (Cernosvitoviella minor, Chamaedrilus glandulosus s.l., Ch. cognettii, Globulidrilus riparius).

b. Young Scots pine forest (Pinus sylvestris), on the edge of a Sphagnum mire, stagnant mud with Molinia stocks, $47^{\circ} 24.345^{\prime} \mathrm{N}, 16^{\circ} 33.918^{\prime}$ E, $319 \mathrm{~m}$ a.s.l., 21.05.2014, 13.10.2014 and 24.10.2016. 11 species (Achaeta camerani, A. cf. danica, Cernosvitoviella atrata, C. minor, C. farkasi, Chamaedrilus chlorophilus, Fridericia dura, F. paroniana, Marionina simillima, $M$. vesiculata, Mesenchytraeus pelicensis).

9. Meadow, Hungary, near a Scots pine forest, $47^{\circ} 24.116^{\prime} \mathrm{N}, 16^{\circ} 33.600^{\prime} \mathrm{E}, 297 \mathrm{~m}$ a.s.l., 13.10.2014. 15 species (Achaeta camerani, A. unibulba, Buchcholzia appendiculata, Cernosvitoviella minor, Enchytraeus buchcholzi s.l., Fridericia connata, F. dura, F. galba with 5-8 diverticula, $F$. hegemon, $F$. nemoralis, $F$. ratzeli, $F$. schmelzi, F. semisetosa, $F$. sohlenii, Marionina argentea).

10. Near Hörmann-spring, Hungary, spruce forest, $47^{\circ} 21.493^{\prime} \mathrm{N}, 16^{\circ} 27.642^{\prime} \mathrm{E}, 757 \mathrm{~m}$ a.s.1., 21.05.2014, 13.10.2014, 20.06.2015, 24.10.2016. 12 species (Achaeta cf. danica, A. tothi, Bryodrilus ehlersi, Chamaedrilus chlorophilus, Enchytraeus norvegicus, Enchytronia parva, En. baloghi, Fridericia alpica, Marionina simillima, Mesenchytraeus pelicensis, Oconnorella cambrensis, O. tubifera).

11. Between Hörmann-spring and Velem village, Hungary, mixed forest with $\mathrm{Ca}$ rpinus betulus, Quercus petraea and Pinus 
sylvestris, $47^{\circ} 21.058^{\prime} \mathrm{N}, 16^{\circ} 29.110^{\prime} \mathrm{E}, 467 \mathrm{~m}$ a.s.1., 2014.10.13. 7+1 species (Achaeta tothi, Chamaedrilus chlorophilus, Ch. glandulosus s.l., Fridericia dura, F. sohlenii, Marionina simillima, Mesenchytraeus pelicensis, Hrabeiella periglandulata).

12. Near Hörmann-spring, Hungary, mixed forest with Fagus sylvatica, Quercus robur, Laryx decidua and Vaccinium, $47^{\circ} 22.088^{\prime} \mathrm{N}$, $16^{\circ} 28.277^{\prime}$ E, $667 \mathrm{~m}$ a.s.1., 21.05.2014. 1 species (Marionina clavata).

13. Steirer Houses, Hungary, $47^{\circ} 22.201 \mathrm{~N}$ $16^{\circ} 28.045 \mathrm{E}, 667 \mathrm{~m}$ a.s.l.

a. Mesophile montane hay meadow, 21.05. 2014, 13.10.2014, 20.06.2015, 24.10.2016. 26+1 species (Achaeta affinis, A. bohemica s.s., A. cf. danica, A. tothi, Buchholzia appendiculata, Cernosvitoviella minor, Chamaedrilus chlorophilus, Ch. glandulous s.l., Enchytraeus buchholzi s.l., E. bulbosus, E. sp., Enchytronia christenseni, En. parva, Fridericia benti, $F$. bisetosa, $F$. connata, $F$. connatiformis, $F$. dura, F. maculata, F. miraflores, $F$. nemoralis, $F$. paroniana, $F$. perrieri, $F$. schmelzi, F. semisetosa, F. sohlenii, F. sp. (with only ventral chaeta), Hrabeiella periglandulata).

b. Near „Ciklamen-spring", wet soil under old Picea abies trees, 21.05.2014. 4 species (Enchytraeus lacteus, Fridericia perrieri, Henlea perpusilla, Marionina argentea).

14. Near Steirer Houses, Hungary, mixed deciduous forest with Quercus robur and Fagus silvatica, $47^{\circ} 22.685^{\prime} \mathrm{N}, 16^{\circ} 30.026^{\prime} \mathrm{E}$, $521 \mathrm{~m}$ a.s.1., 21.05.2014. 9+1 species (Buchholzia simplex, Enchytraeus norvegicus, Enchytronia parva, Fridericia bisetosa, $F$. connata, F. alpica, F. dura, F. ratzeli, $F$. sohlenii, Hrabeiella periglandulata).

15. Near Paprét, Hungary, alder carr at Creekside. $47^{\circ} 24.091^{\prime} \mathrm{N}, 16^{\circ} 26.878^{\prime} \mathrm{E}, 478$ m a.s.1. a. Soil and leaf-litter, 21.05.2014, 13.10. 2014, 24.10.2016. 31+1 species (Achaeta affinis, A. camerani, A. cf. danica, Bryodrilus ehlersi, Buchcholzia appendiculata, B. simplex, Cernosvitoviella minor, Chamaedrilus cognettii, Ch. glandulosus s.l., Enchytraeus buchcholzi s.l., E. norvegicus, Enchytronia parva, Euenchytraeus clarae, Fridericia benti, $F$. discifera, F. alpica, F. dura, F. galba with 5-8 diverticula, $F$. perrieri, $F$. phaeostriata, $F$. raxiensis, $F$. ratzeli, $F$. sohlenii, Globulidrilus riparius, Henlea perpusilla, Marionina argentea, Mesenchytraeus armatus, M. glandulosus, $M$. pelicensis, Oconnorella cambrensis, $O$. tubifera, Hrabeiella periglandulata).

b. Decaying bark on tree stumps, 21.05. 2014. 3 species (Bryodrilus ehlersi, Chamaedrilus chlorophilus, Mesenchytraeus pelicensis).

16. Velem, Hungary, creekside area of willow, $47^{\circ} 20.451^{\prime} \mathrm{N}, 16^{\circ} 30.078^{\prime} \mathrm{E}, 325 \mathrm{~m}$ a.s.l., 27. 03.2016, 24.10.2016.

a. Creekside under Salix sp. on the side of the road. $47^{\circ} 20.451^{\prime} \mathrm{N}, 16^{\circ} 30.078^{\prime} \mathrm{E}$ 20+1 species (Achaeta cf. danica, Buchcholzia appendiculata, Cernosvitoviella aggtelekiensis, Chamaedrilus chlorophilus, Ch. glandulosus s.l., Enchytraeus buchcholzi s.l., Enchytronia parva, Fridericia benti, $F$. connata, $F$. dura, $F$. galba with 5-8 diverticula, $F$. miraflores, $F$. paroniana, $F$. perrieri, $\underline{F}$. phaeostriata, F. sohlenii, $\boldsymbol{F}$. szoevenyii sp. n., Henlea perpusilla, Mesenchytraeus armatus, Oconnorella cambrensis, Hrabeiella periglandulata).

b. Creekside under Salix sp. on the other side of the road $47^{\circ} 20.501^{\prime} \mathrm{N}, 16^{\circ}$ 30.173E. 10 species (Buchcholzia appendiculata, Chamaedrilus glandulosus s.l., Enchytraeus buchcholzi s.l., Fridericia benti, F. maculata, F. perrieri, F. phaeostriata, Globulidrilus riparius, Henlea perpusilla, Marionina argentea). 


\section{Appendix 2. List of Enchytraeidae and Hrabeiellidae species recorded in the Köszeg Mountains.}

(the Cernosvitoviella and Achaeta species of this mountain have already been published by Dózsa-Farkas et al. 2017 and Dózsa-Farkas \& Felföldi 2017a)

Achaeta affinis Nielsen \& Christensen, 1959

Achaeta bohemica (Vejdovský, 1879) sensu stricto

Achaeta camerani (Cognetti, 1899)

Achaeta cf. danica Nielsen \& Christensen, 1959

Achaeta tothi Dózsa-Farkas \& Felföldi, 2017

Achaeta unibulba Graefe, Christensen \& DózsaFarkas, 2005

Bryodrilus ehlersi Ude, 1892

Buchholzia appendiculata (Buchholz, 1862)

Buchholzia simplex Nielsen Christensen, 1963

Cernosvitoviella aggtelekiensis Dózsa-Farkas, 1970

Cernosvitoviella atrata (Bretscher, 1903)

Cernosvitoviella farkasi Dózsa-Farkas, Csitári \& Felföldi, 2017

Cernosvitoviella minor Dózsa-Farkas, 1990

Chamaedrilus (Cognettia) chlorophilus Friend, 1913

Chamaedrilus (Cognettia) cognettii (Issel, 1905)

Chamaedrilus (Cognettia) glandulosus sensu lato (Michaelsen, 1888)

Enchytraeus buchholzi Vejdovský,1879 sensu lato

Enchytraeus bulbosus Nielsen \& Christensen, 1963

Enchytraeus lacteus Nielsen \& Christensen, 1961

Enchytraeus norvegicus Abrahamsen, 1969

Enchytraeus sp.

Enchytronia baloghi Dózsa-Farkas, 1988

Enchytronia christenseni Dózsa-Farkas, 1970

Enchytronia parva Nielsen \& Christensen, 1959

Euenchytraeus clarae Bauer, 1993

Fridericia alpica Dózsa-Farkas \& Felföldi, 2017 (in press)
Fridericia benti Schmelz, 2003

Fridericia bisetosa (Levinsen, 1884)

Fridericia bulboides Nielsen \& Christensen, 1959

Fridericia connata Bretscher, 1902

Fridericia discifera Healy, 1975

Fridericia dura (Eisen, 1879) $(=F$. ratzeli sensu Dózsa-Farkas 2005)

Fridericia galba (Hoffm., 1843) with 5-8 diverticula

Fridericia hegemon (Vejdovský, 1878)

Fridericia maculata Issel, 1905

Fridericia miraflores Sesma \& Dózsa-Farkas, 1993

Fridericia nemoralis Nurminen, 1970

Fridericia paroniana Issel, 1904

Fridericia perrieri (Vejdovský, 1878)

Fridericia phaeostriata Dózsa-Farkas, 2015

Fridericia ratzeli (Eisen, 1872) (=F. eiseni DózsaFarkas, 2005)

Fridericia raxiensis Dózsa-Farkas \& Felföldi, 2017

Fridericia schmelzi Cech \& Dózsa-Farkas, 2005

Fridericia semisetosa Dózsa-Farkas, 1970

Fridericia sohlenii Rota et al., 1998

Fridericia szoevenyii sp.n.

Fridericia sp.

Globulidrilus riparius (Bretscher, 1899)

Henlea perpusilla Friend, 1911

Marionina argentea (Michelsen, 1889) sensu lato

Marionina clavata Nielsen \& Christensen, 1961

Marionina simillima Nielsen \& Christensen, 1959

Marionina vesiculata Nielsen \& Christensen, 1959

Mesenchytraeus armatus (Levinsen, 1884) 
Mesenchytraeus glandulosus (Levinsen, 1884)

Mesenchytraeus pelicensis Issel, 1905

Oconorella cambrensis (O'Connor, 1963)

Oconorella tubifera (Nielsen \& Christensen, 1959)
Stercutus niveus Michelsen, 1888

Hrabeiella periglandulata Pižl \& Chalupský, 1984

Parergodrilus heideri Reisinger, 1925 